\title{
Governance and Management of State-Owned Enterprises in Zanzibar: A Proposed Model for Effective Performance
}

\author{
Shaaban Mwinchum Suleiman \\ PhD Candidate, Faculty of Leadership and Management, \\ Universiti Sains Islam Malaysia \\ Corresponding author \\ Abdalla Ussi Hamad \\ PhD Candidate, Institute of Islamic Banking and Finance, \\ International Islamic University Malaysia (IIUM)

\section{Dr. Mashitah Bt Sulaiman} \\ Faculty of Leadership and Management, \\ Universiti Sains Islam Malaysia
}

Doi: $10.2478 / \mathrm{mjss}-2018-0108$

\section{Abstract}

In Zanzibar, the status of SOEs is not as satisfactory as other countries. There has been a countrywide outcry on the performance of SOEs. The purpose of this study therefore, was to examine the governance and management of SOEs, highlight some benefits and challenges as well as propose a model for effective performance. Following the reviews of various literature and government documents, the study on hand has found that the governance of SOEs needs close revision regarding their management structure as there are roles conflicts between the top bureaucrats; the study also found that absence of SOEs policy has been a major bottleneck for the SOEs to perform at a reasonable level as no proper guidelines which direct the SOEs where to go and what to achieve in a specific time period. Furthermore, the study has found that the overstaffing of SOEs in one way or another puts pressure to the management to attain its intended goals resulting to low contribution in the country's economy. The study recommends that SOEs need to be creative and innovative in their undertakings as they have to undertake diversification of their products in order to attract foreign markets significantly. It is also suggested that proper SOEs policy needs to be made in order to give proper directions to the SOEs so that the goal and objectives of their setup can be successfully attained.

Keywords: State Owned Enterprises, Zanzibar, Corporate Governance, Management

\section{Introduction}

Zanzibar is an autonomous part of the United Republic of Tanzania, found in Eastern part of Africa. It consists of two main islands, Unguja and Pemba with a total area of 2,654 sq km. Unguja, which is the largest island, has an area of 1,666 square kilometres while Pemba has an area of 988 square kilometres. It has divided into five regions, three in Unguja (Urban-west, Southern and Northern) and two in Pemba (Northern and Southern), as well as having eleven districts, seven in Unguja (Urban, Western A, Western B, Central, Southern, Northern A and Northern B) and four in Pemba (Mkoani, Chakechake, Wete and Micheweni) (MoSPORASD, 2016, Suleiman \& Hamad, 2016). 
Zanzibar got her independence from Arabs on $12^{\text {th }}$ January 1964 through revolution and united with the then Tanganyika on $26^{\text {th }}$ April 1964 to forge the United Republic of Tanzania. However, with the exception of a few union matters such as foreign policy, defence and internal security, immigration, monetary issues, higher education, customs and exercise duty, Zanzibar retains its autonomy over all non-union matters. This is to say, it has her own Government, which is officially called the Revolutionary Government of Zanzibar (RGoZ), with all three organs of the state which are the Zanzibar House of Representatives (Parliament), Judiciary (The Attorney General and Chief Justice) and an Executive (the Revolutionary Council). The RGoZ has responsibility for matters internal to Zanzibar and for overseeing developments in key sectors in Zanzibar. (Zanzibar Constitution, 1984, Suleiman \& Hamad, 2016).

\subsection{An Overview of SOEs in Zanzibar}

The history of SOEs in Zanzibar began far back before and after the revolution in 1964 (RGoZ, 2003). The major aims of their establishment were to create employment opportunities to the people, provide social services as well as contribute in the country's economy (GDP). During that time, The RGoZ provided various presidential decrees which aimed at establishing these enterprises. One of the main decrees was the Public Enterprise Decree of 1966 which led to the establishment of various enterprises such as Zanzibar Insurance Corporation (ZIC), Zanzibar State Trading Corporation (ZSTC) etc.

During the first two decades after independence, SOEs were seen as the principal instrument to achieve economic development. Consequently, the period from 1964 to 1985 saw a rapid growth of SOEs, where the number increased from 4 in 1960s to 25 in 1990s. They had a monopoly position in many sectors of the economy, including the import and export of all goods. The SOEs contributed as much as 17 percent of GDP, provided 13 percent of employment, and about 60 percent of the total recurrent revenue of the RGoZ. (RGoZ, 2003).

However, starting in the early 1980s, the performance of the SOEs started to decline, and in 1993 the RGoZ recognized the need for the reform of the SOEs. Subsequently the number of SOEs declined from 25 in 1994 to 12 in 2002. It is worth noting that many SOEs turned out to be not economically viable without the support of the Government, and these SOEs ceased to exist as commercial entities, rather than becoming part of the private sector (RGoZ, 2003). During the period of 1990s, different countries especially in the developing world, Zanzibar is not an exception, began the move towards privatisation of their SOEs through the structural adjustment programme (SAP). The assumption was that the new efforts would cater for improved socio-economic developments of the country (Mutahaba \& Kiragu, 2002). In this move, RGoZ took effort to privatise some of its SOEs which were considered as loss making and unproductive, although the pace of privatisation was not very much effective. In this period, it was also witnessed some SOEs ceased functioning due to a number of reasons including poor managerial capacity, absence of corporate governance, overstaffing of employees, low capacity of board of trustees and huge resources drawings by the government (RGoZ, 2003).

In its efforts to rescue the remaining SOEs from collapsing as well as ensuring the effective implementation of the Zanzibar Strategy for Growth and Reduction of Poverty (ZSGRP), which has been introduced in the past two decades, the RGoZ enacted The Zanzibar Public Investment Act (2002), which repealed the Public Enterprise Decree, of 1978. The new act provides full autonomy and mandate to the SOEs in all organisational aspects which are not limited to recruiting, promoting, transferring, firing, remunerating, and the like in order to execute their daily activities effectively and efficiently. Executives and managers of the SOEs are empowered by the prevailing laws to create different organisational environments and climates which may in one way or another make employees perform at their level best and therefore lead to a better organisational performance. Section eleven (11) of the Zanzibar Public Investment Act (2002) provides power on staff appointment of SOEs as seen from the following sub sections $1-5$ here below.

(1) Notwithstanding any law now in force, the staff required for the purpose of a public corporation shall be appointed by the Board.

(2) Promotion and other disciplinary measures relating to the staff of a public corporation shall 
be in the hands of the Board and shall be exercised in accordance with the staff regulation of a public corporation.

(3) Except on Presidential appointment, no employee or officer of any government department or another public corporation shall be transferred to a public corporation except under the staff regulation of a public corporation.

(4) Notwithstanding any provision under this section, any staff of a public corporation may be seconded to a government department or another public corporation and vice-versa for such period and on such terms as may be agreed between such authorities.

(5) For avoidance of doubt, it is expressly provided that the Board shall have the power to employ, terminate, dismiss and suspend staff of a public corporation in accordance with staff regulation on such public corporation.

So far, however, the information above shows a clear responsibility of the management to perform their duties in SOEs. Various researches to date in Zanzibar seem to focus on effectiveness of other government organisations and forget about SOEs despite having $7 \%$ of the government employees and involving in different production activities. Therefore this study will in nutshell examine the governance and management of SOEs in Zanzibar. It highlights the economic contribution of SOEs in Zanzibar. Moreover, it proposes the model for better SOEs management and performance.

\section{Review of Literature}

\subsection{Meaning of State-Owned Enterprises}

State-Owned Enterprises (SOEs) are those companies where, for various reasons, the state exercises control. These are the corporations established under the state laws and which the government or its agent owns majority of shares or is the sole shareholder. The ownership arrangements and the governance structures vary across countries and sectors (UN, 2008). The Organisation for Economic Co-operation and Development (OECD) definition of SOEs are "enterprises where the state has significant control through full, majority, or significant minority ownership" (OECD, 2002). Moreover Chinese government defines SOEs as enterprises in which all assets are owned by the state (Hongying, 2014).

According to the European Union, (2016) State-Owned Enterprises (SOEs) are defined as those companies where, for various reasons, the state exercises control. The ownership arrangements and the governance structures vary across countries and sectors. This shows that every country has its own forms of ownership of SOEs. In Zanzibar context, the definition of SOEs has been well articulated in the Public Investment Act, (2002); where in this Act SOEs have been termed as Public Corporations referring to any corporation in which the government or its agents owns majority of the shares or is the sole shareholder.

These definitions have a clear indication that SOEs are engaging in different businesses in which the government as partner takes part in the ownership of the shares, where it can own all the shares as in the case of Zanzibar, or majority of the shares. Since the 1930s, and particularly after the World War II, numerous SOEs, also called Public Enterprises (PEs) or Public Corporations (PCs), were created in both developed and developing countries to address market deficits and capital shortfalls, promote economic development, reduce mass unemployment, and ensure national control over the overall direction of the economy especially in developing countries (UN, 2008). These organisations produce a broad range of goods and services such as power, communications, steel, fertilizers, automobiles, petrochemicals etc. The performance of these public enterprises varies widely within and between countries, but their record has frequently been poor, particularly in developing countries. They have clearly failed to play the strategic role in industrialization that governments had hoped for (Mahmoud, 1992). For the purpose of this study and clear understanding of the context and contents, the term SOEs will be thoroughly used instead of Public Corporations as both take the same meaning. 


\subsection{Corporate Governance of SOEs}

Central to the entire discipline of state owned enterprises is the concept of corporate governance. In order for the SOEs and other state owned assets to operate efficiently, the government should prepare robust policy towards the success of SOEs. Also the policy helps in strengthening the corporate governance, restructuring and reorganising them (Kabwe, 2011). Corporate governance defines the responsibilities, authorities and accountabilities of owners, boards of directors, executive and managers of a company (Nhema, 2015). Many of the problems that commonly face state owned governance is weakness in corporate governance. This means that good corporate governance is needed in SOEs. The Auditor General Report of Canada, (2005), states that, corporate governance, refers to the process and structure for overseeing the direction and management of a corporation so that it carries out its mandate and objectives effectively (Kabwe, 2011).

\subsection{Contribution of SOEs in Economic Growth}

In the history of development of economics, China is thought as a country which took immense efforts in improving SOEs in deferent ways. The Trade Policy Review in China, published by the World Trade Organization (2011), demonstrates that, there were 1,047 SOEs listed on the Shanghai and Shenzhen stock markets, accounting for $44.7 \%$ of companies listed in China. In the same line, Many SOEs have also been listed in the Hong Kong stock market and other overseas stock markets such as New York, London and Singapore (Hongying, 2014). In India, the study by Mishra (2014) indicated that SOEs contributed to the Central Exchequer by way of dividend payment, interest on government loans and payment of taxes and duties. There was, however, a significant increase in the total contribution of SOEs to the Central Exchequer during the year, which increased from Rs 1, 60,801crore in 2011-12 to Rs 162761.31 during 2012-13. This was, primarily due to increase in contribution towards 'corporate tax' and 'excise duty' which increased from Rs 44358crore to Rs 44612crore during 2011-12 to 2012-13. There was, however, a decline in 'Custom Duty', 'other duties \& taxes' and 'dividend tax' during the year as compared to the previous year. There was also a marginal decline in payment of central sales tax by the SOEs.

\section{Methodology}

This study used secondary data approach where different texts and documents were visited. Authors had access to government documents including national budget speeches, reports and other relevant materials. Mostly data were presented using pie and bar charts in order to give more understanding on the subject matter under discussion. In addition to that some diagrams were used to elaborate more from the contextual contents.

\section{Findings and Analysis}

\subsection{Governance of SOEs in Zanzibar}

The governance and management of SOEs in Zanzibar is currently regulated under the Public Investment Act, No.4 of 2002. However, individual enterprises are also governed by their own Acts. The Public Investment Act gives the power to the President of the Revolutionary Government of Zanzibar to appoint the Chief Executive Officer (CEO) of the enterprise as well as to appoint the chairperson of the Board of Director (BoD). On the other hand the Minister responsible for the Ministry under which a particular SOE is affiliated has been empowered by the Act to nominate members of the BoD, as seen in the figure 1 below.

Structurally, the SOE is governed by the BOD and the CEO (The management team). The $\mathrm{BoD}$ according to the prevailing legislation consists of not less than five and not more than seven members who shall hold office for a period of three years but may be re-appointed for such further period as the responsible minister may determine, while the tenure of the CEO of the SOE to hold office ranges from four to five years, in which the re-appointment of the next term is applicable based on the satisfactory performance. 


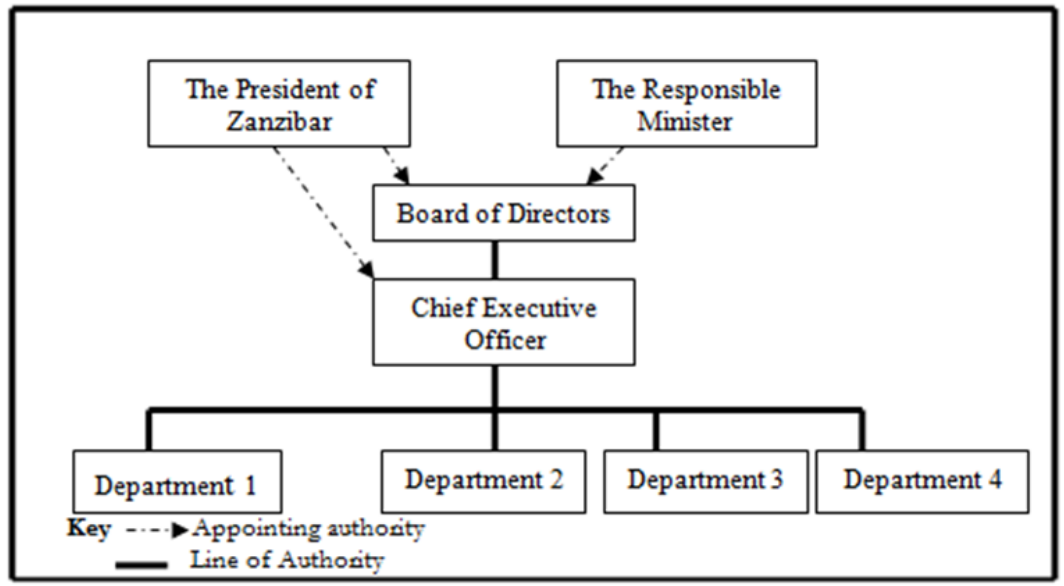

Figure 1: Appointing Authorities and the Structure of the SOE in Zanzibar. Source: RGoZ (2002).

The major functions of the BoD includes the establishing of the system designated to ensure the proper distribution of dividends to shareholders, granting gratuities, benefits and allowances to the officers and employees of the enterprise, exercising supervision over the management team of the enterprise, and also doing any other functions which in the opinion of the Board are important for the enterprise. On the other side, the CEO (the management team) is responsible for the proper day to day administration of the enterprise according to the policy laid down by the BoD, enforcement of staff and financial regulations made the BoD, for the reporting on the activities of the enterprise at every meeting of the BoD and to the Commissioner (RGoZ, 2002)

\subsection{Industry operated by SOEs}

At the present time, there are eleven (11) SOEs in Zanzibar which are operating under diverse industries, although in comparisons with other countries like South Africa, India, China and Malaysia, it is still in infancy level. In banking industry, there is only one bank which is People's Bank of Zanzibar (PBZ); it is a commercial bank dealing with various banking products provided to corporate and retail customers and currently commands about $50 \%$ of the market share in Zanzibar. On the side of the insurance industry, there is Zanzibar Insurance Corporation (ZIC) which deals with transactions of all forms of insurance business, long term and general insurance. Zanzibar State Trade Corporation (ZSTC) is under business and trade industry. The principal function of ZSTC is purchasing and selling cloves, exchanging trade and developing trade resources, technologies, goods and services that facilitate the sustainable growth and development of the clove, agricultural products and allied products. In addition to that it provides extension services in collaboration with other relevant Institutions (www.zstcznz.org).

Moreover, Zanzibar Broadcasting Corporation (ZBC) and Zanzibar Newspaper Corporation (ZNC) fall under media industry where their main function is to disseminate information to different stakeholders through different media like radio, television and newspapers. ZBC possesses ZBC TV and ZBC radio, while ZNC possesses Zanzibar Leo newspaper. In educational industry, there are State University of Zanzibar (SUZA) and the Zanzibar Library Services Board (ZLSB). SUZA is the only public university operating in Zanzibar, although there are other two private universities operating which are Zanzibar University (ZU) and Abdulrahman Al-Sumait Memorial University (formerly University College of Education-Zanzibar). In utility industry, there is Zanzibar Electricity Corporation (ZECO) with the objective of generating, transmitting, distributing, and selling of electricity in Zanzibar. Under this objective ZECO has a role to ensure that Zanzibar population has 
reliable, accessible and good quality electricity at affordable price. It also has the role to deliver better quality services to meet needs and wants of its customers.

Zanzibar Ports Corporation (ZPC) and the Shipping Corporation of Zanzibar (SCZ) cover the marine industry. Their specific objectives are not limited to managing, operating, developing and promoting ports and shipping activities in Zanzibar. The final industry is housing which is under the Zanzibar Housing Corporation (ZHC). This is the latest established corporation (2014) with the aim of facilitating the provision of house, and other buildings to Zanzibaris for residential, commercial, industrial or any other real estate purpose (RGoZ, 2014). One interesting point to note here is that, all these corporations are wholly owned by the RGoZ, this is to say the government possess $100 \%$ of the shares for each corporation.

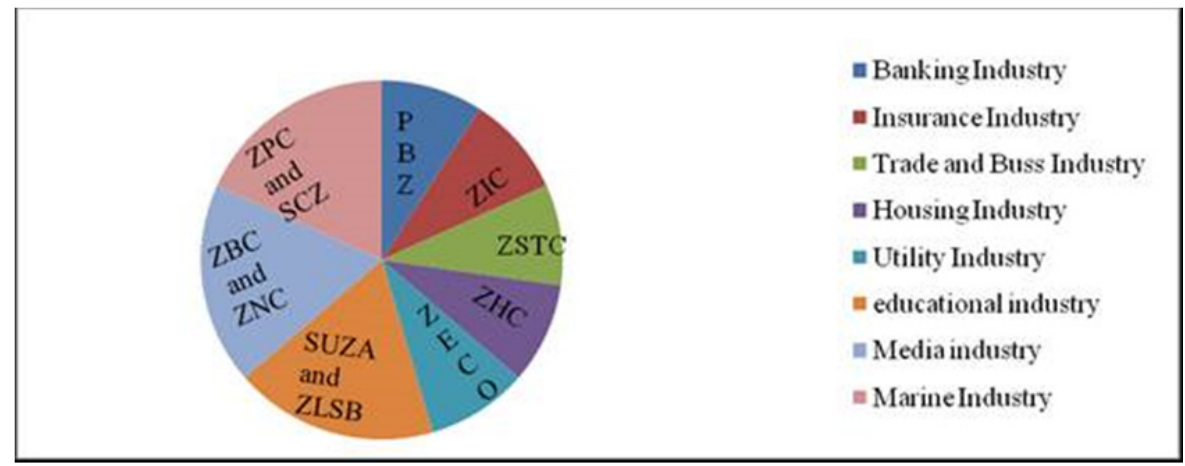

Figure 2: SOEs Industry in Zanzibar

Source: ZPSC (2016).

\subsection{Contribution of SOEs in Economic Growth}

Due to the absence of robust SOEs policy in Zanzibar, the contribution of SOEs in economic growth in the country has been a matter of debate. The Public Investment Act, 2002 requires SOEs to submit a dividend to the treasury based on their profit. According to the data from the government offices, SOEs are required to submit $20 \%$ of their after tax profit to the treasury (RGoZ, 2015). Although the exercise does not go as expected due to the poor financial performance of many of the country's SOEs, the contribution of these organisations currently has been less than $2 \%$ of the GDP, different from the years 1970s and 1980s. Moreover, SOEs employ about $7 \%$ of the total government employees. The figure below indicates the contribution of the SOEs to the Treasury from the years 2011/12 to 2014/15 in USD.

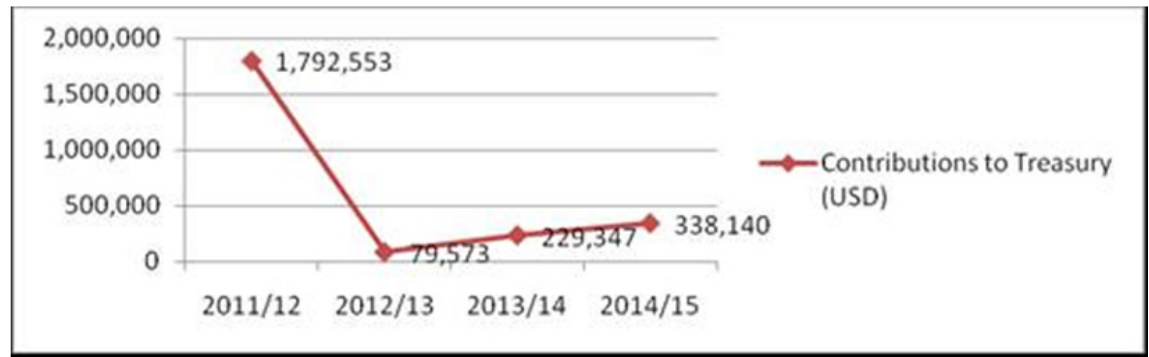

Figure 3: Contributions of SOEs to the Treasury (USD)

Source: ZPSC (2016) 


\subsection{Challenges Facing SOEs in Zanzibar}

\subsubsection{No Policy and strategy to guide Public Enterprises' role in the Economy}

Zanzibar does not have SOEs policy. As a result the government could not clearly determine the development contribution of SOEs and rationalize their structure. In South Africa and India, for instance, governments declared the goal of SOEs as to contribute to sustainable economic and social development. That is to attract Foreign Direct Investments (FDIs), contribute to the reduction in public borrowing and assist in the development of an economy that promotes industrial competitiveness and growth and increased domestic saving. To achieve this, these countries reviewed the sector, developed policy guidance and formulated strategies. They also formed special departments or ministries dealing with SOEs to rationalize the sector and offer strong oversight (Kabwe, 2011).

\subsubsection{Absence of Clear Ownership:}

SOEs in Zanzibar face a typical challenge as a government owned organisation which are yet to see a clear cut boundary between ownership and management. As a consequence, there is a frequent interference of the government in the working of these entities and enterprises are not functioning as Board managed organisations. This leads to slow and poor decision making and bureaucratisation of SOEs (Kabwe, 2011). CEOs as managers of the SOEs know better, but when owners of a firm are not clear about their goals they can hardly expect to achieve them. In private sector, for example, the objective is to maximise returns to their investment, but this is not the case in SOEs in Zanzibar since there are some stakeholders would like to have efficiency, while others want equity but there may be stakeholders who just want to enrich themselves through tenders or outright theft.

\subsubsection{Appointment of the Members of the Boards and Chief Executive Officers}

Currently, Chairpersons of Boards of SOEs in Zanzibar as previously explained are appointed by the President while the members to such Boards are appointed by the Ministers of the Parent Ministries of such SOEs. At the same time, Chief Executive Officers of the SOEs are also appointed by the President, a situation which creates a battle for power supremacy since both parties are appointed by the same authority (Kabwe, 2011). This situation creates friction between the two parties resulting in poor performance of the SOEs.

\subsubsection{The composition of boards of SOEs is an important issue.}

Some Members of the House of Representatives (MHRs) are still serving as members of Boards of Directors of the SOEs which makes the functioning of the Boards of Directors to be impaired. Most of the MHRs appointed to the Boards are not qualified and there is no empirical evidence that their presence in boards has helped to improve performance (Kabwe, 2011). Directorships and senior managerial positions in SOEs are often viewed as political backing positions for retired military and high level civil servants or for relatives and friends of powerful political leaders. This kind of nepotism must end if the country really wants to see SOEs contributing to growth of the country's economy.

\subsubsection{Political interference and Corruption}

SOEs are still facing continuing risks of political interference, of cronyism and corruption in their governance and operations (Kabwe, 2011). In Zanzibar, ineffective SOEs not only have failed to contribute to development but have siphoned-off resources that could have gone to development activities, thus creating significant opportunity costs in our resource-scarce economy. The costs of continuing to give subsidies to unprofitable SOEs have taken a heavy toll on the Treasury. The 
chart below indicates SOEs which have been receiving grants from the Treasury in the years 2011 to 2013.

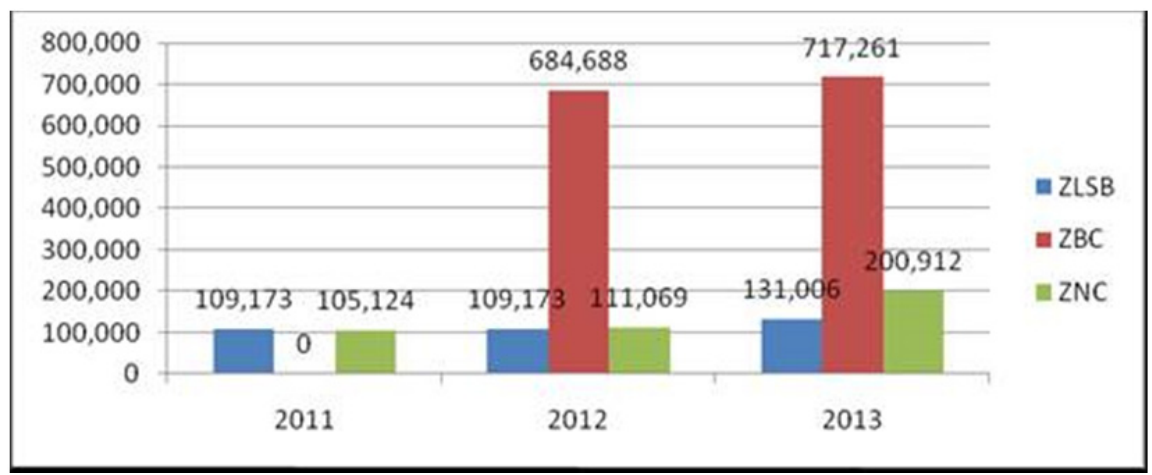

Figure 4: Subsidies Received by some SOEs from 2011 - 2013

Source: ZPSC (2016).

\subsubsection{Overstaffing}

Human resource planning is not effective from which several SOEs like Zanzibar Electricity Corporation (ZECO) and Zanzibar Ports Corporation (ZPC) have extra employees in which two third of the employees are non-skilled or semi-skilled. Staffing is not based on sound labour forecasts. Recruitment is frequently influenced by politicians who pressurise the employment of their relatives. This puts SOEs in a situation of using their budget for more recurrent activities through the payment of salaries and wages other than investing in development programmes. It happened one time the minister responsible for finance urged the SOEs management to reduce the number of employees although his pledge ended in vain (Nipashe, 2016). The figure below indicates employees' enrolment as per the SOEs as at June 2016.

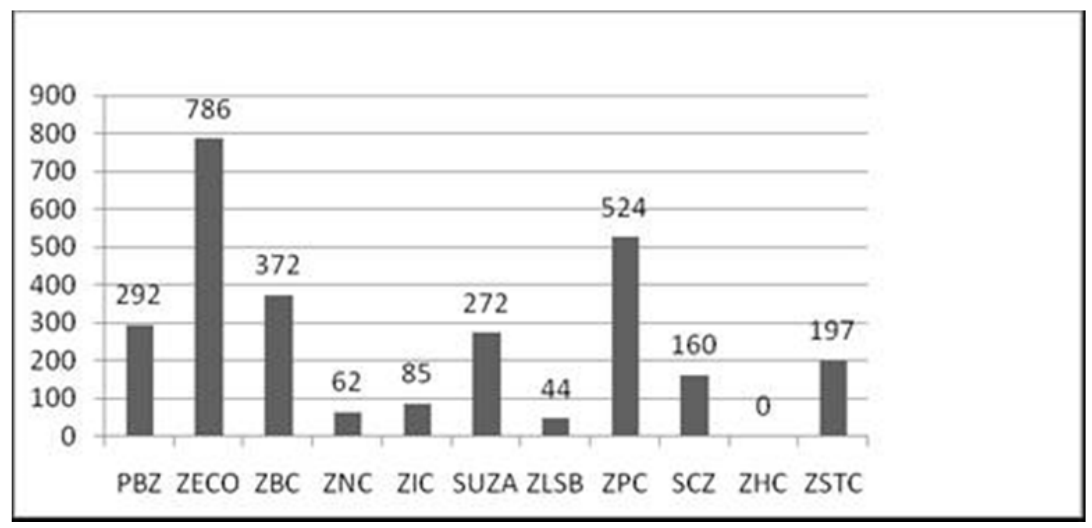

Figure 5: Total Number of Employees per SOE Source: ZPSC (2016)

\subsubsection{Debts facing SOEs}

About six (6) SOEs are in grave situation in meeting short and long term debts. These organisations owed some amount of money from different creditors. This condition may be a threat 
to these organisations as they may not be able to run by themselves and therefore depend on grants from the central government. The fact is that all money which is collected by these organisations may be used to pay back the debts.

Table 1: Debts Facing SOEs in Zanzibar

\begin{tabular}{|c|c|l|c|}
\hline $\mathbf{s} / \mathbf{n}$ & Name of the SOE & Type of the debts & $\begin{array}{c}\text { Amount of the debts } \\
\text { as at 30 August 2014 } \\
\text { USD } 3,617,473 . \\
\text { USD 262,646 }\end{array}$ \\
\hline $\mathbf{1 .}$ & ZPC & $\begin{array}{l}\text { Construction of Ship Tower } \\
\text { Purchase of Ports Equipment }\end{array}$ & $\begin{array}{c}\text { USD } 20,930,233 \\
\text { Euro } 700,000\end{array}$ \\
\hline $\mathbf{2 .}$ & ZECO & $\begin{array}{l}\text { TANESCO arrears } \\
\text { Construction of Electricity Centre, Mpendae }\end{array}$ & $\begin{array}{c}\text { USD } 317,751 . \\
\text { USD } 149,446\end{array}$ \\
\hline $\mathbf{3 .}$ & ZSC & $\begin{array}{l}\text { Long Term debt } \\
\text { Creditor }\end{array}$ & USD 1,209 \\
\hline $\mathbf{4 .}$ & ZLSB & Consortium of TZ University \& Research Libraries & USD 61,347 \\
\hline $\mathbf{5 .}$ & ZNC & Printing Charges & USD 59,870. \\
\hline $\mathbf{6 .}$ & SUZA & Taxes Payable to Tanzania Revenue Authority & \\
\hline
\end{tabular}

Source: ZPSC (2016)

\subsection{The proposed framework for the performance of SOEs in Zanzibar}

Following enormous challenges facing SOEs in Zanzibar, ranging from policy-wise to operational, this paper tries to develop a model which could be implemented in trying solving some of the impairments based on appointments of top officials of the SOE as well as the coordination and harmonisation of the SOEs matters.

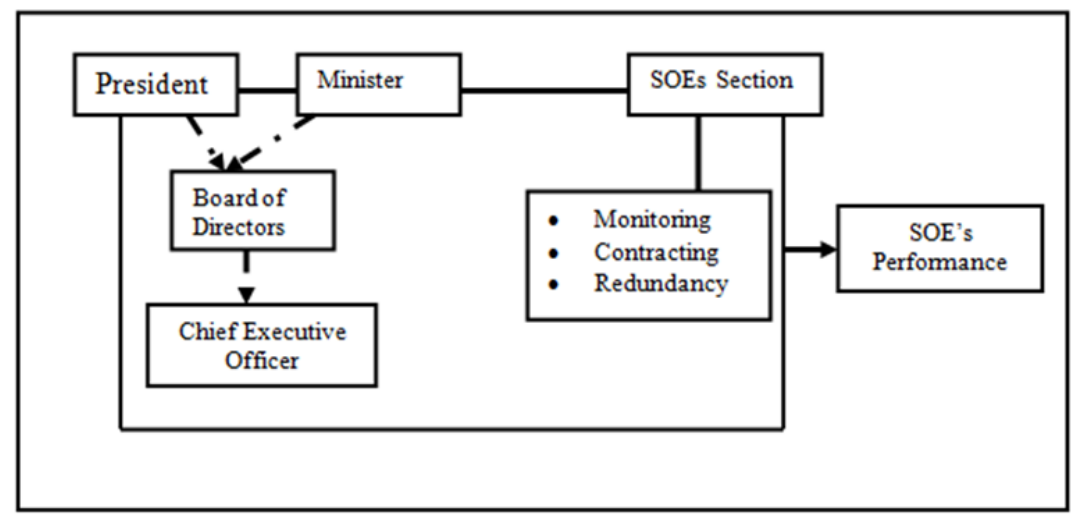

Figure 6: A Proposed Model for Proper Functioning of SOEs

Source: Researchers (2016).

The proposed model holds that the role of the President and the Minster as appointing authorities remains but the presidential power is proposed to appointing the chairman of the BoD only. The role to appoint the CEO of the organisation is laid down to the BoD. This assumption removes the problem of supremacy of power between the chairman of the board and the CEO. Again on the appointment of the members of the BoD, the tendency of involving members of the House of Representatives or former military officers or civil servants on the basis of their political patronage has to be abolished. In this world of business competitiveness, it is proposed that competency and expertise in a related filed should be the first priority for all appointing authorities i.e the President, the Minister and the BoD. 
Furthermore, the model also proposes the introduction of a specific Section/ Unit which will deal with all SOEs. The Section is responsible for government oversight of all SOEs. The functions of this Section will basically base on monitoring, contracting, redundancy and other related issues. It shall sign performance contracts (PCs) with SOEs Boards and enforce them; Boards consequently must sign PCs with CEOs with clear goals and objectives. As so far, SOEs in Zanzibar do not have a policy which guides them on their operationalisation as well as specific targets. The examples of South Africa, China and India point out that the policy is needed to ensure proper functioning of these SOEs. Although these countries established specific ministries to deal with SOEs, for the start Zanzibar could introduce only a Section which can be placed in one ministry for instance the Ministry of Finance and Economic Affairs. Parent Ministries of SOEs shall only be responsible for sectoral policy matter and not operational.

In addition to that, the model as well proposes that among the functions of the Section will be to plan on the SOEs employees' redundancy programme. As explained earlier that one of the major challenges of the SOEs in Zanzibar is overstaffing. Employees' redundancy is so fragile, as it touches the interests of different stakeholders in the community, thus failing to address it apropriately could create more losses than gains. Having one proper programme for the redundancy across the SOEs could minimise the fear of unknown to employees. It is believed that the programme could be fair, just and equal to all employees.

\section{Conclusion}

This study has tried to show various developments of SOEs in Zanzibar together with their contributions and challenges. It has been vividly seen that the performance of SOEs in Zanzibar is in the infancy stage, which in one or another retards the rapid growth of the country's economy. Despite the fact that the government has been taking different measures to make SOEs perform better, there is still more to be done. In light with above statement, the study suggests that, time has come for the management of SOEs in Zanzibar to exploit the available opportunities in order to improve the wellness of these SOEs. For example, ZECO which has been fully depending on hydro-electric power from Tanzania Electricity Supply Company (TANESCO) could turn its mind to solar and wind energy which is abundant in the country.

Also, the ZSTC as the principal entity for public business in Zanzibar should not only depend on cloves production alone which has been falling remarkably in the recent years due to the cutting down of clove trees as well as some of the trees are very old to produce, but more efforts also need to be directed into other areas including the improvement of spice plantations like cinnamon, cardamom, black-peppers, as well as boosting sea weeds cultivation which altogether guarantee ready foreign markets so as to generate foreign currencies. Moreover, the proposed model may be put into practice by the responsible stakeholders as a remedy to reduce tag of wars between the parties in the SOEs. The study faced various limitations including using secondary data sources as well as engaging mostly on analysing corporate governance.

More research is needed to be conducted on Zanzibar SOEs especially on the issue of the employees' performance. It is indisputable truth that the performance of any organisation depends highly on the qualities and capabilities of its workforce, the environment within which the work is performed as well as the resources invested in the organisation. Understanding the perceptions and preferences of the employees in the SOEs could help management understand what needs to be done to motivate employees and finally achieve the overall organisational goal.

\section{References}

EU (2016) "State Owned Enterprises in the EU: Lessons Learnt and Ways in a Post Crisis Context" Luxembourg Publication Office.

Hongying, G. (2014). Research on China State-Owned Enterprise Professional Managers' Incentive System, 5(11), 227-230.

Kabwe, Z. (2011). Public Enterprises in Tanzania: Challenges and Prospects. In CEOs' Roundatable Conference (pp. 1-10). Dar es Salaam, Tanzania.

Mahmoud, M. F (1992) "Privatisation: A Solution to Problems of Public Enterprises" J. KAU: Econ. \& Adm. 5, 33 - 49. 
Mishra, R. K (2014) "Role of State-Owned Enterprises in India's Economic Development" OECD Paris.

Mutahaba G. and Kiragu K. (2002). "Lessons of International and African Perspectives on Public Service Reform: Examples from five African Countries. African Development, 27, 48-75.

Nhema, A. G. (2015). Privatisation of Public Enterprises in Developing Countries: An Overview. International Journal of Humanities and Social Science, 5(9), 247-256.

Nipashe. (2016, June 2). Mashirika ya Umma Zanzibar ni Mzigo. Nipashe Newpaper. Dar es Salaam, Tanzania.

OECD. (2002). Distributed Public Governance: Agencies, Authorities and other Government Bodies. OECD, Paris.

RGoZ (1984) "The Constitution of Zanzibar", Government Press; Zanzibar

RGoZ (2003) "Zanzibar Public Expenditure Review: Laying Foundations for Improved Public Expenditure Management" Government Press, Zanzibar.

RGoZ (2014) "The Zanzibar Housing Corporation Act, No. 6, 2014" Government Press, Zanzibar

RgoZ (2016) "Ministry of State, Presidents Office, Regional Administration and Special Departments" Zanzibar

RGoZ (2015) "The Budget Speech of the Revolutionary Government of Zanzibar 2015/2016" Government Press, Zanzibar

RGoZ, (2002) "The Public Investment Act, no. 4, 2002", Government Press, Zanzibar.

Suleiman, S. M., \& Hamad, A. U. (2016). Management of Waqf Properties in Zanzibar: Current Situation and the Way Forward. European Journal of Business and Management, 8(33), 94-101.

UN (2008) "Public Enterprises - Unresolved Challenge and New Opportunities" United Nations, New York.

URT (2012) "Population and Housing Census" Government Press, Dar es Salaam; Tanzania.

www.zstcznz.org/ accessed on $17^{\text {th }}$ June, 2016 at 9:15 am.

Zanzibar Public Service Commission (2016) "A Report on Public Corporations Survey" PSC, Zanzibar. 